\title{
ORIENTASI KEAGAMAAN MAHASISWI MUSLIM BERJILBAB DAN MAHASISWI MUSLIM TIDAK BERJILBAB
}

\author{
Fuad Nashorl \\ Univer sitas Islam indonesia
}

\section{INTISARI}

Penelitian ini bertujuan untuk mengungkapkan perbedaan orientasi keagamaan antara mahasiswi Muslim ber jibab dan mahasiswi Muslim tidak berjilbab perguruan tinggi agama dan perguruan tinggi non-agama. Hipotesis yang diajukan dalam penelitian in adalah (a) ada perbedaan orientasi keagamaan antara mahasiswi Muslim berjilbab dan mahasiswi Muslim tidak berjilbab (b) ada perbedaan orientasi keagamaan antara mahasiswa Muslim perguruan tinggi agama dan mahasiswa Musim perguruan tinggi non agama.

Subjek penelitian ini berusia $18-22$ tahun, ber jenis kelamin perempuan, tercatat sebagai mahasiswa Fakultas Psikologi Ull dan Fakultas Psikologi UGM Yogyakarta Jumlah subjek seluruhnya adalah 80 orang. Sebanyak 40 orang berasal dari Fakultas Psikologi UIl dan 40 orang lainnya berasal dari Fakultas Psikologi UGM.

Dała dianalisis dengan menggunakan analisis varians dua jalur. Hasil analisis menunjukkan bahwa terdapat perbedaan yang signifikan dalam hal orientasi keagamaan antara mahasiswi Muslim berilbab dan mahasiswi Muslim tidak berjilbab. Mahasiswa Muslim berjilbab memiliki orientasi keagamaan intrinsik yang lebih tinggi dibanding mahasi swi Muslim tidak bejilbab. Hasil lainnya adalah ada perbedaan orientasi keagamaan antara mahasiswa Muslim PT agama dan PT non-agama. Mahasiswa Muslim PT non agama memiliki orientasi keagamaan yang lebih tinggi dari pada mahasiswa Muslim PT agama.

Kata kunci : orientasi keagamaan, mahasiswi Muslim berjilbab, mahasiswi Muslim tidak berjilbab.

H. Fuad Nashori, adalah dosen Fakuitas Psikologi UIl dan direktur Yayasan Insan Kamil rogyakarta. Aktif menulis hasil pemikiran dan hasil penelitian \& berbagai jurnal, majalah. dan harian. Beberapa buku telah ditulisnya, d anteranya Pskologi Islami: Solusi Islam atas Problem-problem Psikologi (1994). Psikologi Islami: Agenda Menuju Aksl (1997), dan Menggapai Keunggulan Isiam: Khotbahkhotbah Jumiat (1997). Aktif juga menangani Yayasan Kasth Al-Arkham Mojokerto dan Yayasan Raudhatul Fata Wonosobo

\section{PENGANTAR}

D alam satu dekado terakhir, terlihat suatu tenomena yang sangat menonjol di Indonesia, yaitu merebaknya pemakaian jilbab atau busana muslimah di kalangan wanita Muslim. Secara normatif, pemakaian jilbab di kalangan wanita Muslim ini didorong oleh niat untuk menyaati perintah Allah SWT. Dalam kitab suci al-Qur'm al-Karim, Alah SWT 
berfirman: Hai Nabi, katakanjah kepada istriistrimu, anak-anak periampuanmu, dan istriistri orang mukmin "Hendaklah mereka me ngulurkan jilbabnya ke selunh tubuh mere ka. Yang dernikian ini supaya mereka lebih mudah untuk dikenal, karena itu mereka tjdak diganggu. Dan, Allah adalah Maha $P$ e ngampun lagi Maha Penyayang" (QS. alAhzab, 33: 59). Di bagian lain dalam kitab suci ini, Allah SWT berfirman: Katakanlah kepada wanita-wanita yang beriman: "Hendaklah mereka menahan pandangannya, dan memelihara kemaluannya, dan janganlah mereka menampakkan perhiasannya, kecuali yang (biasa) tampak dripadanya. Dan, hendaklah mereka menutupkan kain kerudung ke dadanya, dan janganlah menampakkan perhiasannya, kecuali kepada suami mereka, atau ayah mereka atau ayah suami mereka, atau putra-putra mere$\mathrm{ka}$, atau putra-putri suami mereka, atau saudara-saudara mereka, atau putra-putra saudara perempuan mereka" (OS. an-Nuur, 24: 31).

Pamakaian jilbab ini dilakukan ofeh wanița Muslim dari berbagai macam status sosial dan latar belakang kehidupan. Di Indonesia, pernakaian jilbab ini merebak kuat pada awal tahun 1980-an pada beberapa kalangan. Pada awalnya pemakai jilbab adalah siswi di berbagai Sekolah Menengah Umum dan mahasiswi-mahasiswi yang sedang menempuh pendidikan di perguruan tinggi, di samping santriwati d berbagai pondok pesantren. Ketika hendak menggunakan jilbab di sekolah-sekolah atau di kampuskampus, mereka menghadapi tantangan dan halangan. Peraturan pemerintah yang berlaku saat itu adalah setiap siswa sekolah diharuskan mengenakan pakaian standar dengan warna dan ukuran yang telah digariskan oleh pemerintah (c.q Departemen Pendidikandan Kebudayaan Rl). Peraturan tersebut diinterpretasi oleh banyak pimpinan sekolah sebagai keharusan untuk menge- nakan pakaian standar, yaitu hem berlengan panjang atau pendek serta rok sampai futut. Pimpinan sekolah juga menafsirkan bahwa berpakaian lobih lengkap dari itu, yaitu menutup seluruh tubuh dari ujung rambut hingga ujung kaki, dengan perkecualian wajah dan tangan, tidak diperkenankan. Secara ringkas, mengenakan jilbab dalam kelas dilarang keras. Akibat dari penafsiran ini adalah banyaknya larangan bagi siswa putri bejjilbab untuk mengikuti proses belajar mengajar dalam kelas. Sebagai misal, mereka boleh mengikuti pelajaran, tapi hanya dapat dilakukan dari luar kelas. Berbagai pemberitaan d media massa dan has I wawancara langsung yang peneliti lakukan mengungkapkan banyak di antara siswi itu yang terpaksa pindah ke sekolah lain karena pimpinan sekolah mengharuskan mereka melepaskan jibabnya apabila masih berkehendak melanjutkan studi di sokolah tersebut.

Pada akhirtahun 1980-an penggunaan jilbab dibebaskan, baik di sekolah-sekolah maupun di kantor-kantor. Qleh karena itu. akhirnya jilbab menjadi baju yang biasa digunakan di mana-mana, baik di rumah, di sekolah dan kampus, di kantor, maupun d tempat-tempat pelayanan umum lainnya. Mulai awal tahun 1990-an, jilbab digunakan oleh hampir semua kalangan masyarakat Muslim. Pernakai jibab bukan hanya siswi, mahasiswi, dan santriwati, tapi juga ibu rumah tangga, karyawati di berbagai institusi, artis penyanyi, bintang film dan sinetron, wanita karir, dan bahkan anak-anak.

Salah satu kelompok wanita Muslim yang sampai saat ini dinilai paling menonjof dalam hal penggunaan jilbab adalah mahasiswa putri (baca: mahasiswi). Kalau dicermati secara lebih mendalam, mahasiswi Muslim pemakai jilbab itu bukan hanya berada d lembaga pendidikan tinggi yang memiliki misi Islam dan mewajibkan atau mondorong pemakaian jilbab (perguruan tinggi agama), tapi juga berkombang pesat d 
lembaga pendidikan yang tidak bermisi Islam dan tidak mewajibkan atau tidak mendorong pemakaian jilbab (perguruan tinggi sekuler atau perguruan tinggi non-agama). Bahkan, sejumlah hasil pengamatan mengungkapkan bahwa mahasiswi Muslim berjilbabdi berbagai perguruan tinggi nonagama mengenakan jilbab yang lebih panjang (baca: lebih tinggi kualitas berjilbabnya) dibanding mahasiswi Muslim beriilbab yang menempuh pendidikan di perguruan tinggi agama.

Pada awalnya, sikap masyarakat Muslim Indonesia terhadap pemakai jilbab ini terbelah menjadi dua, yaitu proaktif dan antagonistik. Mereka yang proaktif terhadap pemakaian jilbab ini menilai pemakai jibab sebagai wanita yang taat beragama. Karena kesediaannya mengikuti perintah Allah SWT dalam hal berpakaian, pemakai jibab dinilai sebagai orang yang memiliki orientasi keagamaan yang bersifat intrinsik.

Sementara mereka yang antagonistik menilai pemakai jilbab sebagai seseorang yang tidak dapat menyesuaikan diri dengan kehidupan masyarakat indonesia. Mereka menghubungkan peraturan atau kebiasaan tentang cara berpakaian yang berlaku di Indonesia dengan penggunaan jilbab. Penggunaan jilbab, menurut mereka, dapat dinilai sebagai penyimpangan. Karena itu, pada awal tahun 1980-an pemakai jilbab mendapat tantangan yang sangat keras dari kelompok yang antagonistik ini. Banyak pemakai jilbab yang tidak diperkenankan mengikuti pendidikan di dalam kelas, memperoleh pembatasan-pembatasan di sekolah dan di kantor-kantor, memperoleh ancaman terkena drop out di sekolah bila tidak melepas jilbab, dan sebagainya.

Mengingat bahawa sikap antagonistik sebagian masyarakat itu, maka pemakaian jilbab akan menjadi pembeda antara wanita Mustim yang benar-benar ingin melaksanakan perintah Tuhan dengan wanita Muslirn yang tidak begitu peduti dengan perintah Tuhan. Di kalangan mahasiswi Muslim, pemakaian jilbab akan menjadi pembeda antara yang benar-benar dan tidak benar-benar bermaksudi melaksanakan perintah Tuhan. Dalam situasi seperti ini keputusan mengenakan jibab dalam kehidupan sehari-hari adalah wujud nyata dari ketaatan mahasiswi Muslim yang berniat beragama secara total. Dalam ungkapan Gordon W. Alport, mahasiswi yang mengenakan jibab atas dasar niatan untuk melaksanakan perintah Tuhan atau perintah agama dapat dinilai sebagai mahasiswi Muslim dengan orientasi keagamaan intrinsik.

Alport \& Ross (1977) membagi orientasi keagamaan menjadi dua, yaitu orientasi intrinsik dan orientasi ekstrinsik. Seorang mahasiswi Muslim dinilai memiliki orientasi keagamaan intrinsik yang kuat apabila beragama dipandang sebagai upaya "menyerahkan diri kepada Altah". Sementara mahasiswi Muslim dinilai mempunyai nilai ekstrinsik yang menonjot bila ia "menjadikan agama sebagai hal yang bermanfaat baginya".

Separo terakhir dekade 1990-an, mahasiswi pemakai jilbab terus mengalami pertambahan. Kian hari jilbab kian populer. Menurut pengamatan sekilas yang dilakukan peneliti, d perguruan tinggi negeri nonagama pun jumlah mahasiswi Muslim berjilbab lebih banyak dibanding mahasiswi Mus. lim tidak ber jibab ketika mereka mengikuti proses perkuliahan di perguruan tinggi. Lamakelamaan bejilbab berubah menjadi pakaian yang biasa dikenakan wanita Muslim. Jibab berkembang menjadi mode. Sebagai sebuah mode, jibab dikenakan karena sedang menjad trend umum of kalangan wanita Muslim. Dalam situasi seperti ini, saat mengenakan jilbab seorang wanita Muslim tidak setalus dimotivasi oleh niatan untuk taat kepada Alah SWT. Hal ini sebagaimana peneliti amati berdasarkan observasl dan wawan- 
cara yang peneliti lakukan dengan beberapa wanita Muslim. Selanjutnya jilbab berkembang menjadi pakaian umum yang menjadi mode bagi mahasiswi dan tidak selalu melambangkan ketaatan mahasiswi Muslim terhadap perintah Tuhan. Secara sosio-kultural, dapat dikatakan jilbab telah berkembang menjadi kebudayaan populer atau kebudayaan massa bagi mahasiswi Muslim.

Jilbab pada masa kini terkadang bukan perwujudan ketaatan mahasiswi Muslim terhadap perintah-perintah agamanya. Bahkan, sebagaimana yang dituturkan Ni'mah $\mathrm{Ra}$ syid Ridha (1991), kain kerudung justru dija dkan alat untuk mempercantik diri. Perkembangan jilbab sebagai pakaian mode, yang bahkan digunakan untuk mempercantik diri, menimbulkan pertanyaan ulang masihkah mahasiswi Muslim berjilbab mengenakan kewajiban berjilbab semata-mata karena Allah SWT (orientasi intrinsik) atau karena untuk mengikuti mode atau untuk mempercantik diri (orientasi ekstrinsik)?

Penelitian ini hendak menjawab pertanyaan: apakah ada perbedaan orientasi keagamaan antara mahasiswi Muslim berjilbab dan mahasiswi Muslim tidak bejilibab? Benarkah mahasiswi Muslim berjilbab memiliki orientasi keagamaan intrinsik yang lebih tinggi dibanding mahasiswi Muslim tidak bejilbab?

Penelitian ini juga bermaksud melontarkan pertanyaan: apakah ada perbedaan orientasi keagamaana ntara mahasiswi Muslim perguruan tinggi agama dan mahasiswa Muslim perguruan tinggi non-agama?

\section{DASAATEORI}

Salah satu teon psikologi agama yang cukup menarik adalah teori orientasi keagamaan (religious orientation) yang pertamakali dirumuskan Gordon W. Allport. Menurut Allport \& Ross (1977), tipe orientasi keagamaan dapat dibagi menjadi orientasi keagamaan intrinsik dan orientasi keagamaan ekstrinsik. Mereka menggunakan pendekatan motivasional untuk menjelaskan tipologi tersebut dengan mengistilahkan motivasi intrinsik dan motivasi ekstrinsik yang masing-masing memiliki karakteristik yang berbeda. Harapdisadari semenjak awal bahwa orientasi keagamaan intrinsik-ekstrinsik bukanlah dua hal yang berdiri sendiri, dan terpisah satu sama lain, tetapi merupakan dua hal yang saling berkelanjutan atau kontinum (continum). Orang tidak dapat dimasukkan ke dalam salah satu macam orientasi keagamaan begitu saja dan selalu demikian. Orientasi keagamaan seseorang cenderung mengarah ke salah satu ujung kutub. Pendapat bahwa orientasi keagamaan bersifat kontinum bipolar didukung hasil penelitian Strickland \& Shaffer (Hunt \& King. 1977), yang menemukan bahwa aitem intrinsik dan aitem ekstrinsik berkorelasi negatif.

MenurutAllport \& Ross (1977), cara tersingkat untuk menerangkan karakteristik kedua kutub penghayatan agama adalah dengan mengungkapkan bahwa individu yang termotivasi secara intrinsik akan "menghidupi" agamanya. Sebaliknya, individu yang termotivasi secara ekstrinsik akan "memanfaatkan" agamanya. Mereka mengungkapkan pula bahwa kebanyakan individu (bilamana ia menganut suatu agama) menampikan model afiliasi keagamaan yang terletak pada bentangan antara kedua kutub d atas.

Menjadi jelas bagi kita, objek psikologis yang diteropong oleh Allport dan Ross (1977) melalutipologi ekstrinsikdan intrinsik yang diperkenalkarnya, adalah motivasi dan visi psikologis yang melatarbelakangi kehidupan keagamaan individu. Kalangan yang berorientasi intrinsik akan memiliki motivasi dan visi kehidupan keagamaan yang bersifat fungsional. Sebagaimana ditegaskan oleh Hunt dan King (1977), objek studi yang dila- 
kukan oleh Allport dan Ross bukaniah "agama" atau perilaku-perilaku yang dianggap "religius", melainkan motivasi-motivasi yang berkenaan dengan kepercayaan dan praktik religius seseorang.

Allport dan Ross (1977) memaparkan karakteristik kedua orientasi kehidupan keagamaan. Individu dengan orientasi ekstrinsikcenderung memantaatkan agamademi kepentingan-kepentingan sendiri. Istiah tersebut diambil alih dari aksiologi untuk menunjukkan suatu kepentingan yang dilakukan semata-mata demi melayani kepentingan-kepentingan lain yang bagi individu itu bersifat lebih pokok. Individu yang menganut orientasi keagamaan ekstrinsik akan memandang agama dalam rangka kegunaan untuk berbagai hal, antara lain untuk memperoleh rasa aman, penghiburan, pembenaran diri, keyakinan yang dipeluknya cenderung dianut atau dilambangkan secara selektif agar cocok dengan kebutuhan-kebutuhannya yang lebih primer. Bagi mereka, agama berguna untuk mendukung keperca yaan diri, memperbaiki status, bertahan melawan kenyataan atau memberi sanksipada suatu cara hidup. Dengan begitu, dapat dikatakan bahwa individu di atas "memantaatkan" agamanya.

Sementara individu yang berorientasi keagamaan intrinsik menunjukkan motivasi kehidupan keagamannya dalam agama yang dianutnya. Kebutuhan-kebutuhan lain, sekuat apapun juga, danggap kurang begtu berarti dan sedapat mungkin diintegrasikan dajam keselarasan dengan keyakinan dan ajar an-ajaran agama atau ajaran-ajaran Tuhan. Setelah memeluk suatu keyakinan, individu yang bersangkutan berusaha menginternalisasikan dan mengikuti ajaran agama secara pen uh. Dalam pengertian demikian. dapat dikatakan bahwa individu tersebut "menghidupi" agamanya.

Definisi-definisi yang dideskripsikan deh Alport tentang orientast kehidupan ke agamaan dalam berbagai karyanya bukanlah merupakan suatu ide tunggal. Allport telah memperkenalkan sejumlah variabel yang secara konseptual memang terpisah namun saling berhubungan satu sama lainnya. Berdasarkan penafsiran Hunt dan King (1977) tehadap Intrinsic/Extrinsic Scale dari Alport-Feagin (yangdikembangkan dari hasil sebuah seminar of Harvard di bawah pirmpinan Allport sendiri), beberapa aspek sikap yang berkaitan dengan masing-masing orientasi kehidupan keagamaan adalah sebagai berikut:

Pertama, Personalvs institusional: membatinkan secara personal nilai-nilai ajaran agama sebagai hal yang vital dan berupaya mengusahakan tingkat penghayatan yang lebih dalam vs penghayatan agama yang bersifat institusional atau dalam konteks kelembagaan.

Kedua, Unselfish vs Selfish. berusaha mentransendensikan kebutuhan-kebutuhan yang terpusat kepada diri sendii vs pemuasan diri sendiri, pemanfaatan protektif untuk kepentingan pribadi.

Ketiga, Relevansi terhadap keseluruhan kepribadian, memenuhi kehidupannya dengan motivasi dan makna religius vs terpilahkan atau tidak terintegrasikan ke dalam keseluruhan pandangan hidupnya.

Keempat Kepenuhan penghayatan keyakinan: beriman dengan sungguh-sungguh dan menerima keyakinan agamanya secara penuh tanpa syarat vs iman dan kepercayaan dihayati secara dangkal; keyakinan dan ajaran agama tidak dihayati secara penuh.

Kelima, Pokok dan instrumental: keyakinan agama sebagai tujuan akhir vs keyakinan agama sebagai sarana (intrinsik vs ekstrinsik secara aksiologis).

Keenam, Asosiasional vs komunat, kotertibatan religius demi pencarian nilai religius yang lebih dalam vs afialiasi demi sosiabilitas dan status. 
Ketujuh, Keteraturan penjagaan perkembangan iman, penjagaan iman yang konsisten dan teratur vs ketidakteraturan penjagaan perkembangan iman atau perhatian terhadap perkembangan iman yang bersifat periferal.

Dari penjelasan tujuh aspek orientasi keagamaan tersebut penulis menyimpulkan bahwa individu yang memiliki orientasi keagamaan instrinsik akan memandang agama dengan perspektif yang bersifat personal, unselfish, maknawi, penuh penghayatan, pokok, asosiasional, serta mengusahakan imannya secara konsisten. Individu yang berorientasi intrinsik akan menghayati dan merealisasikan (dalam wujud tingkah laku ajaran-ajaran agama yang dipahaminya secara sungguh-sungguh dan tidak akan terjebak untuk memantaatkan agamanya demi kepentingan-kepentingan pribadi. Kepentingan pribadi yang dimaksud di sini contohnya: untuksosialisasi, mendapatkan rasa aman, memperoleh keuntungan ekonomispolitis. Sedangkan individu yang memiliki orientasi ekstrinsik akan mempersepsi dengan prespektif yang institusional, selfish, agama tidak terintegrasikan dalam keseIUruhan pandangan hidupnya, penghayatan yang dangkal, keyakinan agama sebagai sarana, komunal, serta ketidakteraturan pemeliharaan dan perkembangan iman.

Mahasiswi Muslim yang berjilbab mencoba menghayati dan melaksanakan perintah agama dengan bersungguh-sungguh. Mereka berjilbab semata-mata karena perntah agama yang mereka terima dengan penuh keikhlasan dan kerelaan. Dengan demikian mahasis wi Muslim berjilbab dapat disebut sebagai mahasiswi Muslim yang memiliki orientasi keagamaan intrinsik.

Mahasiswi Muslim ada yang menempuh studi d PT agama (berisi agama) dan df PT non-agama (iidak bervisi agama tertentu). Keadaan di lapangan menunjukkan bahwa PT non-agama justru memberi peluang un- tuk pengembangan keagamaan seseorang.

\section{HIPOTESIS}

Hipotesis pertama penelitian ini adalah ada perbedaan orientasi keagaam antara mahasiswi Muslim berjilbab dengan mahasiswi Muslim tidak berilibab. Mahasiswi Muslim berjilbab mempunyai orientasi keagamaan intrinsik yang lebih menonjol dengan mahasiswi Muslim tidak berjilbab.

Hipotesis kedua penelitian ini adalah ada perbedaan orientasi keagamaan antara mahasiswi Muslim dari perguruan tinggi agama dan mahasiswi Muslim dari perguruan tinggi non-agama. Mahasiswa Muslim dari perguruan tinggi non-agama memiliki orientasi keagamaan intrinsik yang lebih menonjol dibanding mahasiswi Muslim dari perguruan tinggi agama.

\section{Metode}

Subjek penelitian adalah (a) beragama Islam, (b) berjenis kelamin putri, (c) berada pada tahap remaja akhir atau berusia antara 18-22 tahun, dan (d) tercatat sebagai mahasiswa Fakultas Psikologi Unl dan Fakultas Psikologi UGM. Subjek penelitian berjumlah 80 orang. Dalam penelitian subjek dikelompokkan menjadi dua, yaitu mahasiswi Muslim berjilbab dan mahasiswi muslim tidak berilibab.

Yang dimaksud mahasiswi Muslim berjilbab adalah seseorang dengan jenis kelamin wanita yang menyatakan diri beragama Islam dan menggunakan jilbab secara konsisten dalam ruang dan waktu tertentu. Penggunaan jitbab ditandai deh penggunaan pakaian yang menutupi aurat (anggota (ubuh), terkecuali air muka dan telapaks tangan. Dalam penelitian ini seseorang hanya disebut ber jlbab bila mengenakan busana muslimah dalam semua atau sebagian besar kesempatan, baik ketika berada df 
kampus, di rumah, maupun di tempat-tempat umum. Dari segi waktu, yang dapat digolongkan sebagai mahasiswi berjilbab adalah mereka yang sekurang-kurangnya mengenakan jilbab selama satu bulan.

Sementara yang dimaksud mahasiswi Muslim tidak berjilbab adalah seseorang dengan jenis kelamin warita yang menyatakan diri beragama Islam dan tidak pernah mengenakan jilbab atau mengenakan jilbab secara tidak konsisten. Seseorang disebut tidak konsisten mengenakan jilbab bila di salah satu di antara tiga tempat ini, yaitu kampus, rumah, dan tempat umum, tidak mengenakan jibab. Seorang mahasiswi yang mengenakan jilbab hanya pada kesempatan tertentu (misalnya d kampus, di numah, atau d ternpat um un saja) tidak dapat digolongkan sebagai berjilbab.

Penelitian ini menggunakan subjek ma hasiswi Muslim berjilbab dan mahasisiwi Muslim tidak berjilbab dari Fakultas Psikologi Universitas Islam Indonesia dan dari Fakultas Psikologi Universitas Gadjah Mada. Mahasiswi Muslim dari Fakultas Psikologi Ull adalah subjek dari lembaga pendidikan tinggi agama. Penggolongan ini didasarkan kepadamisi UII yang bermaksud menghasilkan sarjana yang dapat mengintegrasikan ilmu pengetahuan dan teknologi dengan Islam. Mahasiswi Muslim Fakultas Psikologi Universitas Gadjah Mada adalah subjek dari lembaga pendidikannon-agama. Penggolongan ini didasarkan pada misi UGM yang secara tidak khusus mengarahkan subjek didiknya untuk menjadi sarjana yang Islami.

Cara pengambilan sampel dilakukan dengan menggunakan teknik pumposive sampling. Dengan teknik ini mahasiswi yang berjilbab dan tidak berjilbab memperoleh kesempatan yang sama untuk menjadi subjek. Pengisi angket yang memiliki kriteria di atas dikategorikan sebagai subjek. Sementara pengisi angket yang tidak meme- nuhi salah satu syarat digugurkan sebagai subjek. Subjek yang memenuhi syarat adalah 60 mahasiswi Muslim dari Fakultas Psikologi UH dan 60 mahasiswi muslim dari Fakultas Psikologi UGM.

Pengambilan data pada penelitian ini akan dilakukan melalui metode angket. Dalam penelitian ini ada satu angket yang digunakan, yaitu adaptasi dan perluasan skala orientasi keagamaan (religion orientation scalef yang disusun Feagin. Skala ini meliputi aspek-aspek (a) personal versus institusional, (b) unselfish versus selfish, (c) relevansi terhadap keseluruhan kehidupan, (d) kepenuhan penghayatan keyakinan, (e) pokok vs instrumental, (f) assosional us komunal, dan (g) keteraturan penjagaan perkembangan iman.

Pola dasar pengukuran Rellgious Orientation Scale versi Feagin ini mengikuti pola metode skala Likert. Pilihan subjek dalam menjawab hanya terdiri dari lima katagori: sangat setuju, setuju, netral, tidak setuju dan sangat tidak setuju. Adapun kriteria pemberian nilai adalah sebagai beriku: untuk aitem intrinsik yang bertungsi sebagai aitem favorable, jawaban sangat setuju mendapat nilai 5 , setuju 4 , tidak setuju 2 . dan sangat tidak setuju 1. Sedangkan unluk aitem ekstrinsik yang berfungsi sebagai unfavorable, jawaban sangat setuju mendapat nilai 1 , setuju 2, tidak setuju 4 , dan sangat tidak setuju 5. Jawaban netral atau tidak dapat menentukan jawaban pada aitem intrinsik maupun ekstrinsik memperoleh sekor 3.

Penelitian Feagin terhadap 285 sample subjek (122 subjek pria dan 163 wanita) dengan rentangan usia 18-50 tahun, yang terdiri dari beragai katagori pekerjaan, pendidikan dan penghasilan, menunjukkan bahwa skala versi Feagin ini secara konsisten mendemonstrasikan validitas konstruknya (Robinson \& Shaver, 1973). Berkaitan dengan validitas skala, aitem-aitem skala ter- 
sebut memiliki koef isien korelasi antara 0,22 $-0,54$ terhadap keseluruhan skalanya.

Untuk menjarnin adanya skala adaptasi yang memiliki kesahihan dan keandalan dalam mengukur konstruksi teoritis sasaran maka skala orientasi kehidupan keagamaan selain tetap mengungkapkan isi keseluruhan butir-butir dalam Religious Origntation Scale, juga diadakan beberapa penyesuaian menurut konteks lokasi penelitian (Indonesia) dengan disertai penambahan beberapa butir baru. Dengan demikian secara keseuruhan skala orientasi kehidupan keagamaan bermaterikan 30 butir yang mencakup tujuh aspek sikap, dan terdiri dari 16 butir favourable (intrinsik) dan 14 butir unfavourable. Hasil Li coba dengan mengggunakan subjek mahasiswa baru yang dilakukan Widyana (1995) mentnjukkan bahwa Skala Orientasi Keagamaan memiliki reliabilitas sebesar 0,816 dan validitas bergerak antara
$0,226-0,477$. Penelitian ni menggunakan ska la tersebut dengan pertimbangan subjek penelitian ini memiliki ciri-ciri yang sama dengan subjek uji coba Skala Orientasi Keagamaan yang dilakukan Widyana (1995).

Semakin banyak jawaban favourable dari subjek akan meningkatkan skor yang diperoleh, yang artinya semakin intrinsik orientasi kehidupan keagamaannya. Sebaliknya, semakin banyak jawaban unfavourable menurunkan skor yang diperoleh, ini menunjukkan semakin ekstrinsik orientasi kehidupan keagamaannya.

Di samping angket di atas, peneliti menggunakan angket tambahan untuk mendapatkan tambahan informasi mengenai: usia subjek, pendidikan subjek, semenjak kapan mulai menggunakan jilbab, di mana saja subjek mengenakan jilbab (di kampus, di rumah, dan di tempat (m um), dan sebagainya.

HASIL

Tabel 1

Rangkuman Analisis Variansi 2-Jalur

\begin{tabular}{|l|r|r|r|r|r|c|}
\hline \multicolumn{1}{|c|}{ Sumber } & \multicolumn{1}{|c|}{ JK } & o & FK & F & R & P \\
\hline Antar A & 274.094 & 1 & 274.094 & 3.764 & 0.043 & 0,053 \\
Antar B & 653.170 & 1 & 653.170 & 8.969 & 0.102 & 0,004 \\
Inter AB & 0.154 & 1 & 0.154 & 0.002 & 0,000 & 0,962 \\
Dalam & 5.462 .082 & 75 & 72.828 & - & - & - \\
\hline Total & 6.389 .500 & 78 & - & - & - & - \\
\hline
\end{tabular}

\section{Keterangan:}

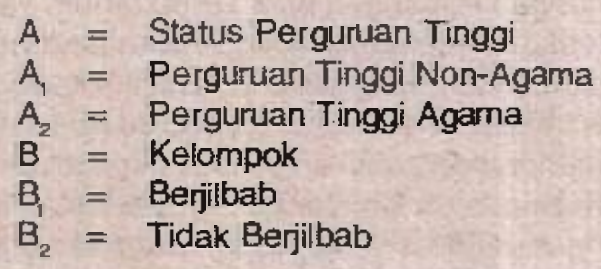


Tentang analisis data, menurut Singarimbun dan Effendi (1988), analisis data penelitian ini dilakukan dengan tujuan menyederhanakan data ke dalam bentuk yang lebih mudah dibaca dan diinterpretasikan. Untuk proses ini digunakan statistik, karena memang salah satu fungsi statistik adalah menyederhanakan data. Untuk mendukung hipotesis yang diajukan dalam penelitian ini, maka akan dilihat perbedaan orientasi keagamaan antara mahasiswi Mustim berjilbab dan mahasiswi Muslim tidak berjilbab. Untuk meliha! perbedaan orientasi keagamaan tersebut, akan dilakukan analisis data dengan menggunakan analisis analisis variant dua jalur.

Hipotesis penelitian yang berbunyi mahasiswi Muslim berjilbab memiliki orientasi keagamaan intrinsik lebih tinggi daripada mahasiswi muslim tidak berjibab, dapat diterima $(p<0,004)$.

Hipotesis penelitian yang berbunyi bahwa mahasiswi Muslim dari periguruar tinggi non-agama lebih linggi orientasi keagamaannya dibanding wanita Muslim dari pergunuan tinggi agama dapat diterima $(p<0,053)$.

\section{DISKUSI}

Dari penelitian ini dapat diketahui bahwa mahasiswi Mustim bejilbab memiliki tingkat orientasi keagamaan intrinsik yang lebih tinggi dibanding mahasisiwi Muslim tidak berjitbab. Dengan demikian, adanya dugaan sebagian orang bahwa penggunaan jilbab pada saat ini lebih merupakan mode daripada kelaatan beragama, ternyata tidak terbukti. Mahasiswi Muslim berjilbab mengenakan busana muslimah itu dimotivasi oleh dorongan yang bersifat internal. Apa yang mereka lakukan merupakan perwujudan dari niatan untuk menaati perintah Allah SWT, sebagaimana yang tertulis dalam kitab suci al-Qur'an surat an-Nuur (24) ayat 31 dan Surat al-Ahzab (33) ayat 59.
Dalam perspektif Allport \& Ross (1977), mahasiswi Muslim berjibab memiliki orientasi religius intrinsik. Kalangan orientasi keagamaan intrinsik memiliki motivasi dan visi psikologis yang bersifat religius. Mereka menandang agama sebagai comprohensive commitment dan driving integrating motive. Bagi mereka, agama adalah pemandu dalam kehidupannya. Mereka memiliki kerelaan untuk mewujudkan ajaran-ajaran dalam kehidupannya. Setiap gerak langkahnya diupayakan dapat dilakukan sebagaimana agama mengajarkannya. Orang-orang semacam ini memiliki kesediaan untuk mengorbankan waktu dan tenaganya untuk menghidup-hidupkan agamanya. Kehidupan mahasiswi berjilbab diarahkan untuk menegakkan eksistensi agama dalam kehidupan nyata.

Secara umum dapat dikatakan bahwa walau zaman terus berubah, mahasiswi Muslim berjilbab tetap memegang teguh agama sebagai dasar dalam berpikir, bersikap, dan berperilaku. Walaupun tantangan dan halangan untuk mengenakan jilbab saat ini retatif berkurang, tetapi motivasi dan visi berjilbab tidak mengalami perubahan. Se cara hakiki, apa yang terjadi pada tahuntahun terakhir ini (tahun 1990-an) tidak berbeda dengan apa yang terjadi pada tahun 1980-an, yaitu wanita Muslim berjilbab secara konsisten tetap memiliki alasan yang sama untuk mengenakan jilbab, yaitu dalam rangka mematuhi aturan-aturan yang terdapat dalam ajaran agamanya.

Selanjutnya, tentang hasil penelitian bahwa mahasiswi Muslim dari perguruan tinggi non-agama justru memiliki orientasi keagamaan intrinsik lebih tinggi daripada mahasiswi Muslim perguruan tinggi agama, hal ini adalah temuan yang menarik. Harap dicatat bahwa subjek penelitian ini adalah mahasiswi Muslim angkatan tahun pertama dan tahun kedua. Pada masa ini mereka memperoleh banyak stimulasi peningkatan pengetahuan maupun motivasi beragama $\mathrm{d}$ 
kampus mereka. Setelah dicermati di lapangan diketahui bahwa upaya-upaya untuk meningkatan pengetahuan dan motivasi keagamaan $d$ dua jen is lembaga tersebut sa. ma-sama dilakukan. Bedanya adalah di perguruan tinggi agama pendidikan agama lebih banyak bersifat legal-formal. Biasanya hubungan pengasuh dan mahasisiwi Muslim sebagai peserta relatil tidak akrab dan cenderung kaku. Sementara d lembaga pendidikan tinggi non-agama pendidikan (upaya peningkatan pengetahuan dan motivasi) agama lebih banyak bersifat informal, d samping pelembagaan bersifat formal yang sangat terbatas. Karena sifatnya yang informal, maka terdapat keluwesan yang lebih besar bagi pengelola pendidikan agama $d$ perguruan tinggi non-agama untuk melakukan proses peningkatan pengetahuan dan motivasi beragama.

\section{PENUTUP}

Kesimpulan dari penelitian ini adalah ada perbedaan dalam hal orientasi keagamaan antara mahasiswi Muslim berjilbab dan mahasiswi Muslim tidak berjibab. Mahasiswi muslim berjilbab memiliki orientasi keagamaan intrinsik yang lebh tinggi dibanding mahasisiwi Muslim tidak berjilbab. Kesimpulan yang lain adalah ada perbedaan orientasi keagamaan antara mahasiswi Muslim dari perguruan tinggi agama dan perguruan tinggi non-agama. Mahasiswi Muslim dari perguruan tinggi non-agama memilikl orientasi keagamaan intrinsik yang lebih menonjol dibanding mahasiswi dari perguruan tinggi agama.

Adapun saran yang hendak kami sampaikan adalah sebagai berikut: Pertama saran untuk penelitian selanjutnya. Penelitian dapat mengungkap perbedaan orientasi religius antara wanita muslim berjilbab. berIllbab secara tidak konsisten, dan yang tidak pernah menggunakan jibab. Penelitian se- lanjutnya dapat juga melihat etos keria, motit berprestasi antara wanita Mustim berjilbab dan wanita Muslim tak berjilbab, dan seterusnya.

Kedua, saran untuk wanita Muslim pada umumnya. Untuk mempertegas keagamaan, salah satu cara yang dapat dipakai adalah mencoba menghayati dan melaksanakan ajaran agama, khususnya perintah beriilbab (QS an-Nuur ayat 31 dan QS al-Ahzab ayat 59). Upaya untuk menaati ajaran agama pada salah satu aspek ini diharapkan akan menghadirkan pengalaman-pengalaman psikologis dan spiritual bagi pernakainya. Pada gilirannya nanti diharapkan mereka akan meningkat derajat ketaatannya dan kepatuhannya kepada ajaran-ajaran agama.

\section{DAFTAR PUSTAKA}

A.hman. M. 1991. Batas Kebebasan Pergaulan Muda-Mudi Istam. Surabaya: $\mathrm{CV}$ Bintang Pelajar.

A-Gahtany. 1989. Kepada Wanila: Islarn dan Potret Wanita di Balik Citra Modern. Surabaya: Pustaka Progresif.

Al-Khayat, M.U. 1997. Muslimah loeal of Mata Pria. Bandung: Pustaka Hidayah.

Allport, G.W. dan Ross, M.1977. Personal Religious Qrientation and Prejudice. Dalam H.N. Malony (Ed.), Current Perspectives in The Psychology of Religion. Michigan: William B. Ee rdmans Publishing $\mathrm{Co}$.

Ancok, D. dan Suroso, FN. 1995. Psikologi Islam: Solusi islam alas Probiem-problem Psikologi. Cetakan ke-2. Yogyakarta: Penerbit Pustaka Pelajar.

As-Sayyid, A.B.A. 1993. Kepada Para Pendidik Muslim. Cetakan ke-5. Jakarta: Gema Insan Press. 
Bastaman, H.D. 1995. Integrasi Psikologi dengan Islam: Menuju Psikologi Islami, Editor: Fuad Nashori, Yogyakarta: Yayasan Insan Kamil dan Penerbit Pus. taka Pelajar.

Crapps, A.W. 1994. Dialog Psikologi dan Agama: Sejak William James Hingga Gordon W. Alport Yogyakarta: Penerbit Kanisius.

Departemen Agama, 1977. Al-Qur'an dan Terjemahannya. Jakarta: Departemen Agama RI.

Hadi, S. 1984. Metodologi Research, Yogyakarta: Yayasan Fakultas Psikologi UGM.

Hidayat, RT. Surtiretna, N. dan Dania, D. 1993. Khasanah Busana Muslimah. Bandung: Penerbit Pustaka.

Hunt, R.A. \& King, M.B. 1977. The IntrinsicExtrinsic Concept. Dalam H.N. Malony (ed.) Current Perspective in the Psychology of Religion. Michigan: William B. Eerdmans Publishing $\mathrm{Co}$.

Sya'rawi, M. 1991. Wanita Harapan Tuhan. Jakarta: Gema Insani Press.
Nashori, F. (Ed.). 1994. Membangun Paradigma Psikologi Islami, Yogyakarta: Sipress.

Nashori, F. 1997. Menggapai Keunggulan Islam. Yogyakarta: Yayasan Kasih AlArkham \& Pustaka Palajar.

Nashori, F. 1997. Psikologi Islami: Agenda Menuju Aksi. Yogyakarta: Pustaka Pelajar \& Fosimamupsi.

Ridha, N.R. 1991. Tabarruj.Cetakan ke-3. Jakarta: Pustaka Al-Kautsar.

Robinson, J.P. \& Shaver, P.R. 1973. Measures of Social Psychological Attitudes. Michigan: Institute of Social Pesearch, The Institute of Michigan.

Shihab, M.Q. 1995. Untaian Permata Buat Anakku: Pesan Al-Qur'an untuk Mempelai. Bandung: Penerbit Al-Bayan.

Tim Penyusun Kamus Pusat Pembinaan dan Pengembangan Bahasa. 1989. Kamus Besar Bahasa indonesia. Jakarta: Balai Pustaka.

Widyana, A. 1995. Orientasi Religius dan Affectpada Mahasiswa Muslim Universitas Gadjah Mada Angkatan 1994/ 1995. Skripsi (tidak dipublikasikan). Yogyakarta: Fakultas Psikologi UGM. 